\title{
Rate of Gain and Utilization of Feed as Affected by Different Levels of Sugarcane Molasses in Starting, Growing and Fattening Diets for Birds of a Laying and a Broiler Stock
}

\author{
Manuel Soldevila, Ismael Carlo, and Ramón F. Perez ${ }^{1}$
}

\section{INTRODUCTION}

The annual production of blackstrap molasses in Puerto Rico during the year 1966-67 was approximately 49 million gallons. This perhaps is the only energy source produced locally in large quantities at a reasonable price $(2.9$ cents/K.), providing approximately 536 calories of productive energy per penny $v s .292$ for yellow corn.

Rosemberg and Palafox $(6)^{2}$ reported cane molasses can be fed to growing pullets at concentrations up to 34.5 percent of the diet. Similar results were reported for broilers (8). Efficiency of feed conversion was inversely proportional to the concentration of molasses. Rosemberg and Palafox ( $y$ ) reported the potassium salts in molasses as the probable cause of diarrhea. This condition causes a managerial problem of wet litter and reduces efficiency of feed utilization due perhaps to the frequent voiding of the intestinal content. Further mention is made that the water content in molasses also impairs efficiency by reducing the caloric value of the ration.

Unpublished results of 10 of our previous studies, in which diets containing different levels of molasses were evaluated, were inconsistent. Such inconsistency probably can be ascribed to our inability to add molasses homogeneously to the other ingredients, which previously were homogenized for 10 minutes by using a semiautomatic incorporator attached to a 1-ton capacity, single spiral, vertical mixer. Remixing of the diets in an effort to homogenize the feed molasses resulted in the build up of particles against the inner surfaces of the mixer and in some cases clogged the mixer when diets were used containing levels as low as 15-percent molasses. At lower levels, many of the molasses-containing feed masses became attached to the inner walls of the mixer.

The objectives of the studies reported herein were to determine the maximum and optimum levels of cane molasses that may be used in starting, fattening and growing diets for broilers and laying stock.

1 Associate Nutritionist and Associate Professor, Agricultural Experiment Station, Río Piedras, P.R.; Animal Husbandman and Professor, Lajas Substation; and Assistant Professor, Mayagüez Campus, University of Puerto Rico, Mayagüez, P.R.

8 Italic numbers in parentheses refer to Literature Cited, p. 169. 


\section{MATERIAL AND METHODS}

\section{CHICKS OF A LAYING STRAIN}

Two studies were completed during the starting and growing periods using female chicks of the Dekalb strain. During the starting period, the birds were housed in floor pens $3.6 \times 2.3 \mathrm{~m}$. in a barn located at the Lajas Substation. Artificial heat was provided during the first 2 weeks. Five levels of molasses $(0,5,10,15$, and 20 percent) were evaluated using a random block design with three replications of 20 birds each for each of the five treatments. The basal diet is described in the upper part of table 1.

During the growing period the birds were also housed in floor pens $3.6 \mathrm{x}$ $2.3 \mathrm{~m}$. in a barn located at the Lajas Substation. Five levels of molasses $(0,5,10,15$, and 20 percent) were also evaluated using a random block design with three replications of 20 birds each for each of the five treatments. The basal diet used in the growing period is described in the upper part of table 1.

\section{CHICRS OF A BROILER STRATN}

Two studies were completed during the starting and fattening periods with broiler chicks of the Vantress strain. The birds were housed in floor pens $3.6 \times 1.8 \mathrm{~m}$. in a barn located at the Main Station in Río Piedras.

Artificial heat was provided during the initial 2 weeks of the starting period. Five levels of molasses $(0,5,10,15$, and 20 percent) were evaluated in two simultaneous studies using a random block design with three replicates of 20 birds each for each of five treatments. Diets based on yellow corn (A) were used in one of the studies; diets containing yellow corn plus 20 percent coconut meal (B) were used in the other. The two basal diets used in the starting period are described in the lower portion of table 1.

During the fattening period five levels of molasses $(0,5,10,15$, and 20 percent) were evaluated. A random block design of three replications of 20 birds each for each of five treatments was used. The basal diet used in the fattening study is described in the lower portion of table 1.

The molasses containing diets used in the four studies reported were prepared using a new technique developed in our laboratory. The use of this technique resulted in homogeneous dispersion of molasses in levels as high as 20 percent. The technique consisted in preparing homogeneous primers of corn and molasses by adding a maximum amount of molasses to a minimum amount of ground yellow corn. This primer was added in predetermined amounts to the remaining ingredients and mixed in a 100pound capacity, bowl-type mixer.

All ingredients and diets were analyzed for nitrogen, calcium and phosphorus following the methods of the A.O.A.C. (1). The caloric content was 
TABLE 1.-Basal diets used during slarting and growing periods of laying stock, and starting and fattening periods in the broiler studies

\begin{tabular}{l|c|c}
\hline \multicolumn{2}{c}{ Laying Stock } \\
\hline \multicolumn{1}{c|}{ Diet, Ingredients and Composition } & Starting I & Growing II \\
\hline \multicolumn{1}{c|}{ Ingredients } & Percent & Percent \\
Corn, Dent No. 2, ground & 68.6 & 80.5 \\
Cane molasses' & .0 & .0 \\
Soybean meal & 17.7 & 7.7 \\
Tuna fishmeal & 11.0 & 11.0 \\
Skimmed milk, dried & 2.0 & .0 \\
Dicalcium phosphate & .0 & .0 \\
Limestone, feed grade, ground & .0 & .0 \\
NaCl & .5 & .5 \\
Premix & $.2^{2}$ & $.3^{2}$ \\
Crude protein, analyzed & & 18.25 \\
Calcium, analyzed & 20.19 & .91 \\
Phosphorus, analyzed & .97 & .69 \\
Calories, calculated & .71 & 1045 \\
\hline
\end{tabular}

\begin{tabular}{l|c|c|c}
\hline \multicolumn{3}{c}{ Broiler Stock } \\
\hline Diet, Ingredients and Composition & Starting IV A & Starting IV B & Fattening V \\
\cline { 2 - 3 } \multicolumn{1}{c}{ Ingredients } & Percent & Percent & Percent \\
Corn, Dent No. 2, ground & 68.5 & 49.6 & 80.5 \\
Coconut meal & .0 & 20.2 & .0 \\
Cane molasses' & .0 & .0 & .0 \\
Soybean meal & 17.7 & 11.4 & 7.7 \\
Tuna fishmeal & 11.0 & 11.0 & 11.0 \\
Skimmed milk, dried & 2.0 & 2.0 & .0 \\
Animal grease, stabilized & .0 & 5.0 & .0 \\
NaCl & .5 & .5 & .5 \\
Premix & $.3^{2}$ & $.3^{2}$ & $.3^{4}$ \\
Crude protein, analyzed & 20.19 & 19.94 & 18.25 \\
Calcium, analyzed & .97 & 1.15 & .91 \\
Phosphorus, analyzed & .71 & .78 & .69 \\
Calories, calculated & 1003 & 1012 & 1045 \\
\hline
\end{tabular}

1 Molasses added at expense of corn.

${ }^{2}$ Contains 0.0006 vitamin $A / D_{2}(500,000 / 100,000$ I.U./g.); 0.0002 riboflavin; 0.0015 niacin; 0.0004 calcium pantothenate; 0.0250 manganese sulfate ( 75 percent); 0.0500 choline chloride (25 percent); 0.1000 terramycin $(6.6 \mathrm{~g}$. oxytetracycline and $6.6 \mathrm{mg}$. vitamin $\mathrm{B}_{12} / \mathrm{kg}$.); 0.0750 coccidiostat.

Contains 0.0006 vitamin $\mathrm{A} / \mathrm{D}_{2}(500,000 / 100,000$ I.U./g.); 0.0004 riboflavin; 0.0008 niacin; 0.0004 calcium pantothenate; 0.0750 cocciodiostat; 0.0250 manganese sulfate (75 percent); 0.0850 terramycin (12 g. oxytetracycline $+4 \mathrm{mg}$. vitamin $\mathrm{B}_{12} / \mathrm{kg}$.).

Contains 0.0006 vitamin $\mathrm{A} / \mathrm{D}_{2}(500,000 / 100,000$ I.U./g.); 0.0002 riboflavin; 0.0005 calcium pantothenate; 0.0020 niacin; 0.0250 manganese sulfate (75 percent); 0.1000 choline chloride ( 25 percent); 0.1700 terramycin $(7.7 \mathrm{~g}$. oxytetracycline and $5.5 \mathrm{mg}$. vitamin $B_{12} / \mathrm{kg}$.).

S Based on data from National Research Council, Publication 1232, 1964. 
calculated from tabulated values reported by the National Research Council (5).

In all studies the isonitrogenous and isocaloric diets and the water were offered ad libitum. Net liveweight gains and feed utilization were used as comparison criteria. The statistical evaluation of the data was based on the methods of Bose et al. (2), Zelem, (10) and Snedecor (9) using a program developed for Computer 1620.

\section{RESULTS AND DISCUSSION}

\section{CHICKS OF A LAYING STRAIN}

The results from study $I$, conducted during the starting period, are described in table 2. The data demonstrate that all diets were superior $(\mathrm{P}<.01)$ to the diet containing 20 percent molasses; and those containing none or a low level (5 percent) of molasses were superior $(P<.01)$ to the ones containing 10- and 15-percent molasses, while the diet without molasses was better $(P<.05)$ than the one containing 5 percent when growth rate was used as the criterion for comparison. There was a trend for decreased growth with increased level of molasses that was accentuated between the diets containing 5 and 10 percent molasses. There were no differences when the diets were compared as to feed utilization. The overall performance in this study was similar to the results published by Rosemberg ( 8 ).

The results from study II, conducted during the growing period, are shown in the middle of table 2. There were no statistical differences between the treatments in either of the criteria evaluated, although a downward pattern of growth and utilization became apparent with increasing levels of molasses. Nevertheless, the birds grew comparatively better when they consumed the diets containing high levels of molasses, when compared to the performance during the starting period.

The combined data for the starting and growing periods from study III are described in the bottom part of table 2. A nonsignificant decrease in feed utilization with increased level of molasses was noted. When growth rate was compared, the diet containing 0-percent molasses was statistically better $(\mathrm{P}<.05)$ than those containing 15 - and 20-percent molasses. The diet containing 5 percent was better $(P<.05)$ than the one containing 20 percent.

The combined data from study III followed a similar growth trend, imparted during the starting period in study I, while the utilization data follows a similar decrease pattern with increased molasses level in all periods.

\section{CHICKS OF A BROILER STRAIN}

Two concurrent studies, IV, were completed during the starting period and the results obtained are presented in table 3 . In study IV A, the inclu- 
TABLE 2.-Rate of gain, utilization of feed, and comparative feed costs of different diets used in studies conducted during starting, growing, and combined periods with birds of a laying slock

\begin{tabular}{|c|c|c|c|c|c|}
\hline Diet & Molasses & Net gains, : & $\begin{array}{l}\text { Average cost/ } \\
\text { pound of feed }\end{array}$ & $\begin{array}{c}\text { Efficiency of } \\
\text { utilization?. 8. }\end{array}$ & $\begin{array}{l}\text { Feed cost/pound } \\
\text { producedo }\end{array}$ \\
\hline Number & Percent & Pounds & Cents & Feed/Gairs Ralio & Cents \\
\hline \multicolumn{6}{|c|}{ Starting Period-Study $I^{1}$} \\
\hline 1 & 0 & $1.12 \mathrm{a}$ & 5.075 & $2.92 \mathrm{a}$ & 14.82 \\
\hline 2 & 5 & $1.10 \mathrm{~b}$ & 5.017 & $2.86 a$ & 14.35 \\
\hline 3 & 10 & $1.04 \mathrm{c}$ & 4.961 & $2.95 a$ & 14.63 \\
\hline 4 & 15 & $1.04 c$ & 4.904 & $3.11 \mathrm{a}$ & 15.25 \\
\hline 5 & 20 & $1.01 d$ & 4.848 & $3.09 \mathrm{a}$ & 14.98 \\
\hline
\end{tabular}

Growing Period-Study $I^{1}$

\begin{tabular}{r|r|r|r|r|r}
\hline 6 & 0 & $1.17 \mathrm{a}$ & 4.426 & $5.08 \mathrm{a}$ & 22.48 \\
7 & 5 & $1.14 \mathrm{a}$ & 4.371 & $5.43 \mathrm{a}$ & 23.73 \\
8 & 10 & $1.14 \mathrm{a}$ & 4.315 & $5.17 \mathrm{a}$ & 22.31 \\
9 & 15 & $1.12 \mathrm{a}$ & 4.259 & $5.85 \mathrm{a}$ & 24.92 \\
10 & 20 & $1.13 \mathrm{a}$ & 4.203 & $5.80 \mathrm{a}$ & 24.38 \\
\hline
\end{tabular}

Combined Periods-Study III

\begin{tabular}{ll|l|l|l|l|l}
\hline 1 \& 6 & 0 & $2.29 \mathrm{a}$ & 4.650 & $4.03 \mathrm{a}$ & 18.74 \\
$2 \& \&$ & 5 & $2.24 \mathrm{ab}$ & 4.588 & $4.17 \mathrm{a}$ & 19.13 \\
3 \& 8 & 10 & $2.18 \mathrm{ab}$ & 4.538 & $4.11 \mathrm{a}$ & 18.65 \\
$4 \& 9$ & 15 & $2.16 \mathrm{~b}$ & 4.475 & $4.53 \mathrm{a}$ & 20.27 \\
5 \& 10 & 20 & $2.14 \mathrm{c}$ & 4.431 & $4.50 \mathrm{a}$ & 19.94 \\
\hline
\end{tabular}

1 Studies conducted at Lajas Substation: Starting period from March 18 to April 29, 1968; growing period from April 29 to June 10, 1968.

2 Adjusted values.

3eans followed by the same letter do not differ significantly $(P<.05)$.

- Based on values calculated using average prices paid by the Agricultural Experiment Station during 1967 for ingredients used in preparing all diets, plus $\$ 0.50$ for mixing and handling costs. The commercial equivalent costs $\$ 6.30$ and $\$ 6.08 /$ hundredweight for the starting and growing mashes, respectively.

${ }^{5} \mathrm{Kg}$. of feed $/ \mathrm{kg}$. of liveweight gained.

- Obtained by multiplying efficiencies times values described under average cost/ lb. feed.

sion of any amount of molasses in the diets based on corn resulted in a downward trend in growth and utilization with increased levels of molasses. All diets were statistically superior $(P<.01)$ to the one containing 20-per cent molasses, and the one containing 0 -percent was better $(P<.05)$ than the ones containing 10- and 15-percent molasses when growth was evaluated. 
Then diet containing no molasses was superior $(P<.01)$ to all others when utilization of feed was evaluated.

In study IV B, when a diet based on corn plus 20-percent coconut meal was used, inconsistent trends resulted both in growth rate and utilization of feed. There were no statistical differences between the treatments.

The data from the fattening period presented in the upper part of table 4 was inconsistent and no statistical differences were found in either criteria evaluated. Nevertheless, the birds grew more comparatively and utilized

TisLe 3.-Rate of gain, utilization of feed, and comparative feed costs of different diets used in studies conducted during starting period with birds of a broiler strain

\begin{tabular}{|c|c|c|c|c|c|}
\hline Diet & Molasses & Net gaing, , & $\begin{array}{c}\text { Average cost/pound } \\
\text { of feed }\end{array}$ & $\mid \begin{array}{c}\text { Eficiency of } \\
\text { utilizationa. 2. }\end{array}$ & $\begin{array}{l}\text { Feed cost/pound } \\
\text { producedo }\end{array}$ \\
\hline Number & Percent & Pounds & Cents & Feed/Gain/Ratio & Cents \\
\hline \multicolumn{6}{|c|}{ Starting period-Corn diets-Study IV $A^{1}$} \\
\hline $\begin{array}{l}1 \\
2 \\
3 \\
4 \\
5\end{array}$ & $\begin{array}{r}0 \\
5 \\
10 \\
15 \\
20\end{array}$ & $\begin{array}{l}1.47 \mathrm{a} \\
1.42 \mathrm{ab} \\
1.39 \mathrm{~b} \\
1.39 \mathrm{~b} \\
1.23 \mathrm{c}\end{array}$ & $\begin{array}{l}4.974 \\
4.917 \\
4.861 \\
4.804 \\
4.748\end{array}$ & $\begin{array}{l}2.55 a \\
2.79 b \\
2.80 b \\
2.75 b \\
2.78 b\end{array}$ & $\begin{array}{l}12.68 \\
13.72 \\
13.61 \\
13.21 \\
13.20\end{array}$ \\
\hline
\end{tabular}

Starting period-Coconut diets-Study IV $B^{1}$

\begin{tabular}{r|r|r|r|r|l}
\hline 6 & 0 & $1.43 \mathrm{a}$ & 4.715 & $2.50 \mathrm{a}$ & 11.79 \\
7 & 5 & $1.45 \mathrm{a}$ & 4.684 & $2.53 \mathrm{a}$ & 11.85 \\
8 & 10 & $1.51 \mathrm{a}$ & 4.653 & $2.41 \mathrm{a}$ & 11.21 \\
9 & 15 & $1.37 \mathrm{a}$ & 4.622 & $2.53 \mathrm{a}$ & 11.69 \\
10 & 20 & $1.36 \mathrm{a}$ & 4.591 & $2.45 \mathrm{a}$ & 11.25 \\
\hline
\end{tabular}

1 Conducted simultaneously at the Main Station (Río Piedras) from March to April, 1968.

8, 3, 4, 5, 6. See 2, 8, 4, 6, 8 table 2.

the high level of molasses in the diets better, when contrasted to the starting period performance. The pattern of better growth with high level molassescontaining diets, with increased age, also was apparent in birds of a laying strain.

When the combined data from the starting and fattening periods was evaluated, as shown in the lower part of table 4, the combination of diets containing no molasses was superior $(P<.01)$ to the one containing 10 percent molasses, and better $(P<.05)$ than all the others, when efficiency was evaluated. The combination containing 5-percent molasses was better $\left(P^{*}<.05\right)$ than the one containing 10 percent. When rate of gain was eval- 
uated, the combinations containing 0 - and 5 -percent molasses were superior $(\mathrm{P}<.01)$ to the one containing 20 percent, while the diet containing no molasses was better $(\mathrm{P}<.05)$ than the diets containing 10 and 15 percent.

A very important management consideration became apparent. Under the conditions of our combined broiler study where, allowing $0.19 \mathrm{~m}^{2}(2$ feet $^{2}$ ) per bird in contrast to $0.09 \mathrm{~m} .^{2}$ ( 1 foot $^{2}$ ) recommended under practical conditions, the group receiving the diet containing 20-percent molasses produced a caked litter (wood shavings). The group receiving 15-percent

TABLE 4.-Rate of gain, utilization of feed and comparalive feed costs of different diels used in studies conducted during fattening and combined periods with birds of a broiler strain

\begin{tabular}{|c|c|c|c|c|c|}
\hline Diet & Molasses & Net gain2., & $\begin{array}{l}\text { Average cost/ } \\
\text { pound of feed }\end{array}$ & $\underset{\text { utilization }}{\text { Efficiency of s. s }}$ & $\begin{array}{l}\text { Feed cost/pound } \\
\text { produced }\end{array}$ \\
\hline Number & Percent & Pounds & Cents & Reed/Gain/Ratio & Cents \\
\hline \multicolumn{6}{|c|}{ Fattening Period-Study VI } \\
\hline 11 & 0 & $1.28 \mathrm{a}$ & 4.426 & $2.82 a$ & 12.48 \\
\hline 12 & 5 & $1.31 \mathrm{a}$ & 4.371 & $2.70 a$ & 11.80 \\
\hline 13 & 10 & $1.21 \mathrm{a}$ & 4.315 & $2.88 \mathrm{a}$ & 12.43 \\
\hline 14 & 15 & $1.22 \mathrm{a}$ & 4.259 & $2.80 \mathrm{a}$ & 11.93 \\
\hline 15 & 20 & $1.20 a$ & 4.203 & $2.72 \mathrm{a}$ & 11.43 \\
\hline
\end{tabular}

Combined Periods-S

\begin{tabular}{|c|c|c|c|c|c|}
\hline $\begin{array}{lll}1 & \& & 11 \\
2 & \& & 12 \\
3 & \& & 13 \\
4 & \& & 14 \\
5 & \& & 15\end{array}$ & $\begin{array}{r}0 \\
5 \\
10 \\
15 \\
20\end{array}$ & $\begin{array}{l}2.75 a \\
2.73 a b \\
2.61 b c \\
2.61 b c \\
2.44 c\end{array}$ & $\begin{array}{l}4.712 \\
4.651 \\
4.615 \\
4.552 \\
4.484\end{array}$ & $\begin{array}{l}2.67 \mathrm{a} \\
2.75 \mathrm{~b} \\
2.83 \mathrm{c} \\
2.77 \mathrm{bc} \\
2.75 \mathrm{bc}\end{array}$ & $\begin{array}{l}12.58 \\
12.79 \\
13.06 \\
12.61 \\
12.33\end{array}$ \\
\hline
\end{tabular}

1 Conduced at the Main Station (Rio Piedras) April, 1968.

$2,8,4,6,8$. See $2,8,4,5,6$ table 2.

molasses produced litter approaching a caked state. If a higher density of birds had been used, the 15-percent molasses diet would most likely have produced caked litter, so it appears that a 10-percent molasses diet is marginal. This problem will have to be solved prior to making a final recommendation of optimum levels of molasses to use in practical-type diets. The level of usage of molasses in practical-type diets, and up to the limit imposed by managerial considerations, will be determined by the cost of the ration per unit liveweight produced.

Feed-cost data and their relationship to the efficiency of utilization, shown in tables 2,3 , and 4 , indicate the importance of producing least-cost 
rations by using the maximum permissible amounts of cheaper ingredients in diets formulated to maintain proper rate of growth and efficiency of conversion in the animals receiving it. For every set of conditions (ingredient prices, efficiency of utilization obtained and market price for the birds produced) a new economical analysis and evaluation is mandatory.

\section{SUMMARY}

In several studies conducted during the starting and fattening periods of broiler stock, and the starting and growing periods of laying stock, levels as high as 20-percent sugarcane molasses were utilized satisfactorily in practical-type diets by the birds. Variations obtained in the different studies were discussed.

Caked litter resulted with population densities of $0.19 \mathrm{~m}^{2}\left(2\right.$ feet $\left.^{2}\right)$ per bird when a 20-percent molasses diet was used, while semi-caked litter resulted with a level of 15 -percent molasses. These results imply that with densities of $0.09 \mathrm{~m}^{2}$ ( $1 \mathrm{foot}^{2}$ ), equivalent to practical management conditions, a level of 10-percent molasses in diets appears borderline. Further corroboration studies seem to be indicated, to determine and recommend the maximum economical level of molasses in the diet which will not result in a compact litter.

Feed cost data and their relation to the efficiency of utilization in these studies were evaluated. Inconsistent experimental data from previous experiments is discussed. A new technique for the homogeneous dispersion of molasses is described.

\section{RESUMEN}

En varios estudios conducidos durante los períodos inicial y de engorde con aves asaderas, y durante los períodos inicial y de crecimiento con aves de líneas ponedoras, niveles tan altos como 20 por ciento de miel de caña en dietas prácticas fueron utilizados satisfactoriamente por las aves. Se discutieron las variaciones observadas en los diferentes estudios.

En este estudio se usó aserrín como camada, asignándose un área promedio de $0.19 \mathrm{~m} .{ }^{2}$ por ave, o sea, el doble de lo que generalmente se recomienda para condiciones $\left(0.09 \mathrm{~m}^{2}\right)$ comerciales. En esas condiciones, el nivel de un 20 por ciento de miel en la dieta causó una camada compacta y el de un 15 por ciento una semi-compacta. Estos resultados indican que de usarse una densidad poblacional equivalente a la que se acostumbra comericalmente, los niveles de un 15 y un 10 por ciento de miel en la dieta hubiesen causado una camada compacta. Es necesario determinar cual es el nivel máximo económico de miel en la dieta que no causa una camada compacta antes de poder hacer recomendaciones definitivas sobre el particular en el caso de las dietas de las aves para asar. 
Se evaluaron los datos en cuanto al costo del alimento y su relación con la eficiencia de su utilización. Se discutió la inconsistencia de ciertos datos obtenidos en experimentos previos y se describió una nueva técnica para la incorporación homogénea de la miel.

\section{LITERATURE CITED}

1. Official Methods of Analysis of the Association of Official Agricultural Chemists, 10th ed., Wash., D. C., 1965.

2. Bose, R. C., Clatworthy, W. H., and Shrikhande, S. S., Tables of partially balanced designs with two associate classes, Tech. Bull. 107, N. C. Agr. Expt. Sta., 1954.

3. Morassi, J. A., and Soldevila, M., Effects of different combinations of tuna fishmeal, meat meal with bone and soybean meal upon growth rate and utilization of feed by broilers in the starting and fattening periods. (In preparation.)

4. National Research Council, Nutrient requirements of poultry, Publ. 1345, 1966.

5. National Research Council, Joint United States-Canadian Tables of Feed Composition, Publ. 1232, 1964.

6. Rosemberg, M. M., and Palafox, A. L., Response of growing and mature pullets to continuous feeding of cane final molasses, Poultry Sci. 35: 292-303, 1956.

7. - Effect of certain cations in cane final molasses on fecal moisture of chicks, Poultry Sci. 35: 682-6, 1956.

8. Rosemberg, M. M., Response of chicks to graded concentrations of cane final molasses, Poultry Sci. 34: 133-40, 1955.

9. Snedecor, G. W., Statistical Methods, The Iowa State College Press, Ames, Iowa, 1959.

10. Zelem, M., The analysis of covariance for incomplete block designs, Biometrics 18: $309,1957$. 